\title{
Researches on biofuels gasification using the Lurgi process with homogeneous air inlet over the combustion space
}

\author{
Gheorghe Lăzăroiu ${ }^{1}$, Lucian Mihăescu², Gabriel Negreanu², Iulia Simion ${ }^{1 *}$, Dana- \\ Alexandra Ciupăgeanu ${ }^{1}$ \\ ${ }^{1}$ Power Engineering Faculty, University Politehnica of Bucharest, Splaiul Independentei 313, 060042 \\ Bucharest (Romania) \\ ${ }^{2}$ Mechanics and Mechatronics Faculty, University Politehnica of Bucharest, Splaiul Independentei \\ 313, 060042 Bucharest (Romania)
}

\begin{abstract}
The experimental investigations carried out within the present research focus on a simple gasification technology dedicated to biofuels conversion according to the Lurgi procedure. Specifically, an installation with a fixed grill and a homogeneous distribution of the air inlet over the combustion space are considered. In order to provide a thorough background for the experimental research, this paper presents first the challenges related to the air distribution. If for coal gasification the difficulty of the homogeneous penetration of the air inlet within the whole combustion volume is balanced by the possibility of the direct emission of $\mathrm{CO}$ valorization, for biomass gasification this factor becomes fundamental. The original contribution of the technology introduced in this paper assumes an improved combustion process for Lurgi-type gas generators. The experimental installation employed has a particular design, enabling a homogeneous distribution of the air inlet over the entire combustion zone, up to the top of the embers layer. This allows achieving a maximum $\mathrm{CO}_{2}$ content in the flue gas flux, effectively reducing it inside the embers bed. The high calorific value of biofuels used favors developing an efficient combustion process, occurring at high temperatures. Thus, the reduction process of the $\mathrm{CO}_{2}$ is self-controlled. The experimental installation operates at a slow fuel rate, with discontinued supply and precise airflow control. The quality of the gas obtained is evaluated based on the resulting open flame, analyzing its composition.
\end{abstract}

Key words: biomass combustion, biomass gasification, energy recovery, homogeneous air inlet, Lurgi process

\section{Introduction}

The agricultural requirements for energy need an alternative solution for fuel gasification; one of the possible means is by gasification of biofuels, with a special focus on biomass [1]. To this end, it is necessary to develop simple operating methods, both on the fuel supply side and on the air supply side. The novel installation developed explores the possibility of

*Contact person: julia.simion@gmail.com 
building a gas generator with a more flexible operation than the original Lurgi approach, thus being suitable for biofuels, such as wood or agricultural waste.

Employing steam in the gasification process becomes very difficult because assumes a complementary production plant [2]. Therefore, biomass energy valorization methods are of great interest currently [3].

Experimental tests and theoretical models developments are depicted in the literature, addressing global efficiency improvement paths, combustion facilities upgrading and burning parameters optimization [4]-[6].

The rest of the paper is organized as follows. Section 2 presents some general considerations of gasification models, depicting underlying equations, elemental composition of wood samples and process parameters. Further, Sections 3 describes the experimental stand and Section 4 discusses the results. Finally, conclusions are drawn in the last section.

\section{Gasification of biofuels}

Basically, the gasification of solid fuels (including biomass) consists of the thermochemical process converting the organic mass into combustible gases under the action of oxygen [6].

Table 1 presents the reactions that occur during the gasification process.

The first three reactions are the defining ones, representing the formation of $\mathrm{CO}$ and $\mathrm{CO}_{2}$ compounds through the burning of carbon, with the final decomposition of carbon dioxide on the bed of gasifier, with the formation of $\mathrm{CO}$ combustible gas. A gasogenous can only work if the three reactions show stability in time. The remaining reactions are usually a consequence of the dynamics of the thermodynamic reactions from the space charged with solid fuel.

Table 1. The reactions of the gasification process [7]

\begin{tabular}{|c|c|c|}
\hline No. & Reaction & Thermal effect $\left[\frac{\mathrm{kJ}}{\mathrm{kgK}}\right]$ \\
\hline 1 & $\mathrm{C}+\mathrm{O}_{2}=\mathrm{CO}_{2}$ & 34096 \\
\hline 2 & $\mathrm{C}+0,5 \mathrm{O}_{2}=\mathrm{CO}$ & 10276 \\
\hline 3 & $\mathrm{C}+\mathrm{CO}_{2}=2 \mathrm{CO}$ & -13544 \\
\hline 4 & $\mathrm{C}+\left(\mathrm{H}_{2} \mathrm{O}\right)=\mathrm{CO}+\mathrm{H}_{2}, *$ & -9904 \\
\hline 5 & $\mathrm{CO}+0,5 \mathrm{O}_{2}=\mathrm{CO}_{2}$ & 23800 \\
\hline 6 & $\mathrm{CO}+\left(\mathrm{H}_{2} \mathrm{O}\right)=\mathrm{CO}_{2}+\mathrm{H}_{2}, *$ & 3635 \\
\hline 7 & $\mathrm{H}_{2}+0,5 \mathrm{O}_{2}=\mathrm{H}_{2} \mathrm{O}$, water & - \\
\hline 8 & $\mathrm{~S}+\mathrm{O}_{2}=\mathrm{SO}_{2}$ & - \\
\hline 9 & $\mathrm{CH}_{4}+2 \mathrm{O}_{2}=\mathrm{CO}_{2}+2\left(\mathrm{H}_{2} \mathrm{O}\right)$, steam & 67180 \\
\hline 10 & $\mathrm{H}_{2} \mathrm{~S}+1,5 \mathrm{O}_{2}=\mathrm{SO}_{2}+\left(\mathrm{H}_{2} \mathrm{O}\right)$, steam & - \\
\hline 11 & $\mathrm{C}+2 \mathrm{H}_{2}=\mathrm{CH}_{4}$ & 6285 \\
\hline 12 & $\mathrm{CO}+3 \mathrm{H}_{2}=\mathrm{CH}_{4}+\mathrm{H}_{2} \mathrm{O}$ & 17004 \\
\hline
\end{tabular}

$* \mathrm{H}_{2} \mathrm{O}-$ steam

The main benefit of this process is represented by the wider employment range of the resulting gaseous fuel compared to the initial solid fuel (for instance, energy generation technologies using internal combustion engines or gas turbines cannot use solid fuels). Furthermore, the ecological effect can also be taken into account as a contributory factor [8]. Reactions (1), (2) and (3) are heterogeneous reactions, taking place on the separation surface between the solid phase and the gas phase. The rest of the reactions are homogeneous, which take place between the gas phases. The equilibrium of the $C O$ and $\mathrm{CO}_{2}$ gas phases depending on the temperature is showed in Table 2. The formation of hydrogen $\mathrm{H}_{2}$ and methane $\mathrm{CH}_{4}$ depends on the thermochemical cycle of water vapor. The process can be stimulated or only controlled by steam injection into the gas stream. 
Table 2. The equilibrium composition for the reaction between carbon and oxygen

\begin{tabular}{|c|c|c|c|c|}
\hline \multirow{2}{*}{$\begin{array}{c}\text { Temperature } \\
{\left[{ }^{\circ} \mathrm{C}\right]}\end{array}$} & \multicolumn{2}{|c|}{ Experimental values [\%] } & \multicolumn{2}{c|}{ Calculated values [\%] } \\
\cline { 2 - 5 } & $\mathrm{CO}$ & $\mathrm{CO}_{2}$ & $\mathrm{CO}$ & $\mathrm{CO}_{2}$ \\
\hline 450 & 0.6 & 99.4 & - & - \\
\hline 550 & 10.7 & 89.3 & 11 & 89 \\
\hline 650 & 39.8 & 60.2 & 39 & 61 \\
\hline 800 & 93.0 & 7.0 & 90 & 10 \\
\hline 925 & 96.0 & 4.0 & 97 & 3 \\
\hline
\end{tabular}

Scientific literature depicts several gasification models [2], presented in the following:

A. Gasification process using air, oxygen and air enriched with oxygen

The general reaction for gasification of biofuels using air, oxygen and oxygen enriched oxygen can be expressed as in eq. (1) [8]:

$$
\begin{aligned}
& \mathrm{CH}_{a} \mathrm{O}_{b} \mathrm{~N}_{c} \mathrm{~S}_{d}+w \mathrm{H}_{2} \mathrm{O}+n\left(n_{\mathrm{O}_{2}} \mathrm{O}_{2}+n_{\mathrm{N}_{2}} \mathrm{~N}_{2}\right) \\
& \rightarrow n_{\mathrm{H}_{2}} \mathrm{H}_{2}+n_{\mathrm{CO}} \mathrm{CO}+n_{\mathrm{CO}_{2}} \mathrm{CO}_{2}+n_{\mathrm{H}_{2} \mathrm{O}} \mathrm{H}_{2} \mathrm{O}+n_{\mathrm{CH}_{4}} \mathrm{CH}_{4}+n_{\mathrm{N}_{2}} \mathrm{~N}_{2} \\
& +n_{\mathrm{NO}} \mathrm{NO}+n_{\mathrm{NO}_{2}} \mathrm{NO}_{2}+n_{\mathrm{SO}_{2}} \mathrm{SO}_{2}
\end{aligned}
$$

Where: $\mathrm{CH}_{\mathrm{a}} \mathrm{O}_{\mathrm{b}} \mathrm{N}_{\mathrm{c}} \mathrm{S}_{\mathrm{d}}$ represents the general formula of the biofuel, for which the detailed composition is given in Table $3 ; w$ is the moisture content, $n$ represents the ratio given by kmoles of agent / kmoles of biofuel entered in the gasifier; $\mathrm{n}_{\mathrm{O}_{2}}$ is the number of kmoles of oxygen, $\mathrm{n}_{\mathrm{H}_{2}}$ is the number of kmoles of hydrogen, $\mathrm{n}_{\mathrm{CO}}$ is the number of kmoles of carbon monoxide, $\mathrm{n}_{\mathrm{N}_{2}}$ is the number of kmoles of nitrogen, $\mathrm{n}_{\mathrm{H}_{2} \mathrm{O}}$ is the number of kmoles of water, $\mathrm{n}_{\mathrm{CO}_{2}}$ is the number of kmoles of carbon dioxide, $\mathrm{n}_{\mathrm{CH}_{4}}$ is the number of kmoles of methane, $\mathrm{n}_{\mathrm{NO}}$ is the number of kmoles of nitrogen oxide, $\mathrm{n}_{\mathrm{NO}_{2}}$ is the number of kmoles of nitrogen dioxide, $\mathrm{n}_{\mathrm{SO}_{2}}$ is the number of kmoles of sulfur dioxide.

By applying the mass balance for hydrogen, carbon, oxygen, nitrogen and sulfur, the relations between the coefficients $\mathrm{n}_{\mathrm{H}_{2}}$ and $\mathrm{n}_{\mathrm{SO}_{2}}$ are determined. Based on the ultimate analysis of several biomass types (in particular wood, paper, municipal solid waste and sawdust), Table 3 presents their compositions taking into account a single carbon atom. Specifically, the chemical formula for solid biofuels will be:

$\mathrm{CH}_{1,44} \mathrm{O}_{0,66} ; \mathrm{CH}_{1,55} \mathrm{O}_{0,766} \mathrm{~N}_{0,00593} ; \mathrm{CH}_{1,15} \mathrm{O}_{0,518} \mathrm{~N}_{0,0216} \mathrm{~S}_{0,0047}$ and $\mathrm{CH}_{1,4} \mathrm{O}_{0,599} \mathrm{~N}_{0,004}$.

Table 3. Characteristics of anhydrous fuels [3], [8]-[10]

\begin{tabular}{|c|c|c|c|c|c|c|c|}
\hline Biomass & $\begin{array}{c}\mathrm{C} \\
{[\%]}\end{array}$ & $\begin{array}{c}\mathrm{H} \\
{[\%]}\end{array}$ & $\begin{array}{c}\mathrm{N} \\
{[\%]}\end{array}$ & $\begin{array}{c}\mathrm{S} \\
{[\%]}\end{array}$ & $\begin{array}{c}\mathrm{O} \\
{[\%]}\end{array}$ & $\begin{array}{c}\text { Ash } \\
{[\%]}\end{array}$ & $\left.\begin{array}{c}\text { Thermal } \\
\text { effect } \\
{[\mathrm{kJ} / \mathrm{kmol}}\end{array}\right]$ \\
\hline Wood & 50 & 6 & 0 & 0 & 44 & - & 449568 \\
\hline Paper & 43.4 & 5.8 & 0.3 & 0.2 & 44.3 & 6 & 454864 \\
\hline Municipal solid waste & 47.6 & 6 & 1.2 & 0.3 & 32.9 & 12 & 433034 \\
\hline Sawdust & 52 & 6.07 & 0.28 & 0 & 41.55 & 0.1 & 485294 \\
\hline
\end{tabular}

For modelling purposes, scientific literature introduces a series of coefficients to define anhydrous fuels, as given in Table 4. 
Table 4. Coefficients that define anhydrous fuels [2]

\begin{tabular}{|c|c|c|c|c|}
\hline Biomass & $\mathrm{A}$ & $\mathrm{b}$ & $\mathrm{c}$ & $\mathrm{d}$ \\
\hline Wood & $1.44 \pm 0.0047$ & $0.66 \pm 0.00079$ & 0 & 0 \\
\hline Paper & $1.59 \pm 0.0055$ & $0.766 \pm 0.001$ & $0.00593 \pm 0.00019$ & $0.0034 \pm 0.00017$ \\
\hline $\begin{array}{c}\text { Municipal solid } \\
\text { waste }\end{array}$ & $1.51 \pm 0.0052$ & $0.518 \pm 0.00072$ & $0.0216 \pm 0.00018$ & $0.0047 \pm 0.00015$ \\
\hline Sawdust & $1.4 \pm 0.0046$ & $0.599 \pm 0.00071$ & $0.004 \pm 0.00014$ & 0 \\
\hline
\end{tabular}

The moisture content per unit of biomass can be determined based on the moisture content (MC), as showed in eq. (2) [8]:

$$
w=\frac{M_{\text {biomass }} \times M C}{M_{\mathrm{H}_{2} \mathrm{O}} \times(1-M C)} \times 100 \quad[\%]
$$

where $M_{\text {biomass }}$ and $M_{\mathrm{H}_{2} \mathrm{O}}$ are the molecular weight of the biofuel and water, $\mathrm{MC}$ is the moisture content per mole of biomass. The main reactions that occur in the gasification process are as introduced in the following, according to [6]:

$$
\begin{gathered}
\mathrm{C}+\mathrm{CO}_{2}=2 \mathrm{CO} \\
\mathrm{C}+\mathrm{H}_{2} \mathrm{O}=\mathrm{CO}+\mathrm{H}_{2} \\
\mathrm{C}+2 \mathrm{H}_{2}=\mathrm{CH}_{4}
\end{gathered}
$$

Based on eq. (3) and (4) it can be obtained by specific operations the following relation, as given in eq. (6):

$$
\mathrm{CO}+\mathrm{H}_{2} \mathrm{O} \leftrightarrow \mathrm{CO}_{2}+\mathrm{H}_{2}
$$

Table 5 lists the parameters of the gasification process.

Table 5. Input data [4], [5], [11]

\begin{tabular}{|l|c|}
\hline Air inlet temperature & $298[\mathrm{~K}]$ \\
\hline Biomass inlet temperature & $298[\mathrm{~K}]$ \\
\hline Temperature of syngas existing gasifier & $1073[\mathrm{~K}]$ \\
\hline Environmental pressure & $1.013[\mathrm{bar}]$ \\
\hline Environmental temperature & $298[\mathrm{~K}]$ \\
\hline Pressure of gasifier & $1.013[\mathrm{bar}]$ \\
\hline Molar composition of environmental air & $21 \% \mathrm{O}_{2}, 79 \% \mathrm{~N}_{2}$ \\
\hline
\end{tabular}

\section{B. Gasification process with steam}

The general reaction of the gasification process of a biofuel using steam can be expressed by eq. (7):

$$
\begin{aligned}
\mathrm{CH}_{a} \mathrm{O}_{b} \mathrm{~N}_{c} \mathrm{~S}_{d}+w \mathrm{H}_{2} \mathrm{O} & +m\left(\mathrm{H}_{2} \mathrm{O}\right) \\
\rightarrow & n_{\mathrm{H}_{2}} \mathrm{H}_{2}+n_{\mathrm{CO}} \mathrm{CO}+n_{\mathrm{CO}_{2}} \mathrm{CO}_{2}+n_{\mathrm{H}_{2} \mathrm{O}} \mathrm{H}_{2} \mathrm{O}+n_{\mathrm{CH}_{4}} \mathrm{CH}_{4}+n_{C} C_{(s)}
\end{aligned}
$$

where $\mathrm{CH}_{a} \mathrm{O}_{b} N_{c} S_{d}$ is the general formula of the biofuel, $w$ is the moisture content of the biomass and $m$ is the molar ratio between steam and biomass.. In the scientific literature, the steam to biomass mass ratio (STBM), is defined and used as follows [12]

$$
S T B M=\frac{M_{\mathrm{H}_{2} \mathrm{O}} \times m}{\left(M_{\text {biomass }}+M_{\mathrm{H}_{2} \mathrm{O}} \times w\right)}
$$

The dominant chemical reactions that take place in the steam gasification process are [12]:

$$
\begin{aligned}
& \mathrm{CH}_{4}+\mathrm{H}_{2} \mathrm{O} \leftrightarrow \mathrm{CO}+3 \mathrm{H}_{2} \\
& \mathrm{CO}+\mathrm{H}_{2} \mathrm{O} \leftrightarrow \mathrm{CO}_{2}+\mathrm{H}_{2}
\end{aligned}
$$

The equilibrium constants for the methane decomposition reaction (9) and the gas-water reaction (10) can be written as follows [12]: 


$$
\begin{gathered}
K_{1}=\frac{n_{C O} n_{H_{2}}^{3}}{n_{C_{H_{4}} n_{\mathrm{H}_{2} \mathrm{O}}}}\left(\frac{P / P_{\text {ref }}}{n_{\text {tot }}}\right) \\
K_{2}=\frac{n_{\mathrm{H}_{2}} n_{\mathrm{CO}_{2}}}{n_{\mathrm{CO}} n_{\mathrm{H}_{2} \mathrm{O}}}\left(\frac{P / P_{\text {ref }}}{n_{\text {tot }}}\right)
\end{gathered}
$$

where $P$ is the gas pressure (bar), $P_{\text {ref }}$ is the reference pressure, and the number of moles of the gas elements produced corresponds to the general equation, $K_{1}$ and $K_{2}$ are equilibrium constants that can be related to the Gibbs function as follows [10]:

$$
\begin{gathered}
-\frac{\Delta G_{1}^{0}}{\bar{R} T_{g}}=\ln K_{1} \\
-\frac{\Delta G_{2}^{0}}{\bar{R} T_{g}}=\ln K_{2}
\end{gathered}
$$

where $\Delta G_{1}^{0}$ and $\Delta G_{2}^{0}$ are modifications of the Gibbs free energy for the methane decomposition reaction and $T_{g}$ is the gas temperature.

Considering the general equation of steam gasification, the equilibrium equations for carbon, hydrogen and oxygen can be written as:

$$
\begin{gathered}
n_{\mathrm{CO}}+n_{\mathrm{CO}_{2}}+n_{\mathrm{CH}_{4}}+n_{\mathrm{C}}-1=0 \\
2 n_{\mathrm{H}_{2}}+2 n_{\mathrm{H}_{2} \mathrm{O}}+4 n_{\mathrm{CH}_{4}}-a-2 w-2 m=0 \\
n_{\mathrm{CO}}+2 n_{\mathrm{CO}_{2}}+n_{\mathrm{H}_{2} \mathrm{O}}-b-w-m=0
\end{gathered}
$$

To validate the steam gasification model using wood, the theoretical data reported by [8] can be used for a gasification temperature of $1073 \mathrm{~K}$ and a moisture content of $25 \%$.

The comparison between the percentage component of the gas obtained from the paper [8] with those from the specialized literature is presented in Table 6.

Table 6. Percentage component of gas obtained from steam gasification of biofuels

\begin{tabular}{|c|c|c|c|c|c|c|}
\hline Components & Hydrogen & $\begin{array}{c}\text { Carbon } \\
\text { monoxide }\end{array}$ & $\begin{array}{c}\text { Carbon } \\
\text { dioxide }\end{array}$ & Water & Methane & Nitrogen \\
\hline Results reported by [5] & 44.58 & 23.51 & 9.44 & 16.56 & 0.07 & 0 \\
\hline $\begin{array}{c}\text { Theoretical results } \\
\text { reported by [11] }\end{array}$ & 46.57 & 25.84 & 10.30 & 17.11 & 0.09 & 0 \\
\hline
\end{tabular}

C. Functional aspects and performance analysis of air gasification

The efficiency of carbon conversion is defined by the relation:

$$
\eta=\frac{12\left(\mathrm{CO}+\mathrm{CO}_{2}+\mathrm{CH}_{4}+2.5 \mathrm{C}_{m} \mathrm{H}_{n}\right)}{22.4\left(\frac{298}{273}\right) \times C} \times G_{V} \times 100 \quad[\%]
$$

The efficiency of the gasification is defined by the relation:

$$
\eta=\frac{H_{\text {ggas }}^{i} \times G_{V}}{H_{\text {f fuel }}^{i}} \times 100 \quad[\%]
$$

where $H_{i g a s}^{i}\left[\frac{\mathrm{kJ}}{\mathrm{Nm}^{3}}\right]$ - is the lower calorific power of the generated gas, and $H_{i f u e l}^{i}\left[\frac{\mathrm{kJ}}{\mathrm{kg}}\right]$ - is the lower calorific power of the fuel. The speed of the reactions depends on the thermal level first, followed by the effect of concentration and pressure [13]. The reaction rate for two substances having the concentrations $C_{A}$ and $C_{B}$ is given by eq. (20):

$$
W=K C_{A}^{m} C_{B}^{n}
$$

where $m$ and $n$ are the stoichiometric coefficients of the reaction, and $K$ is the reaction rate constant.

In Table 2 is presented the equilibrium composition, for various temperatures, for the basic reduction reaction for $\mathrm{CO}_{2}$ on the embers bed. The thermochemical processes in the body of 
a gasifier are shown in Figure 1, highlighting moreover the particularities of the updraft flow and the downdraft flow [14].
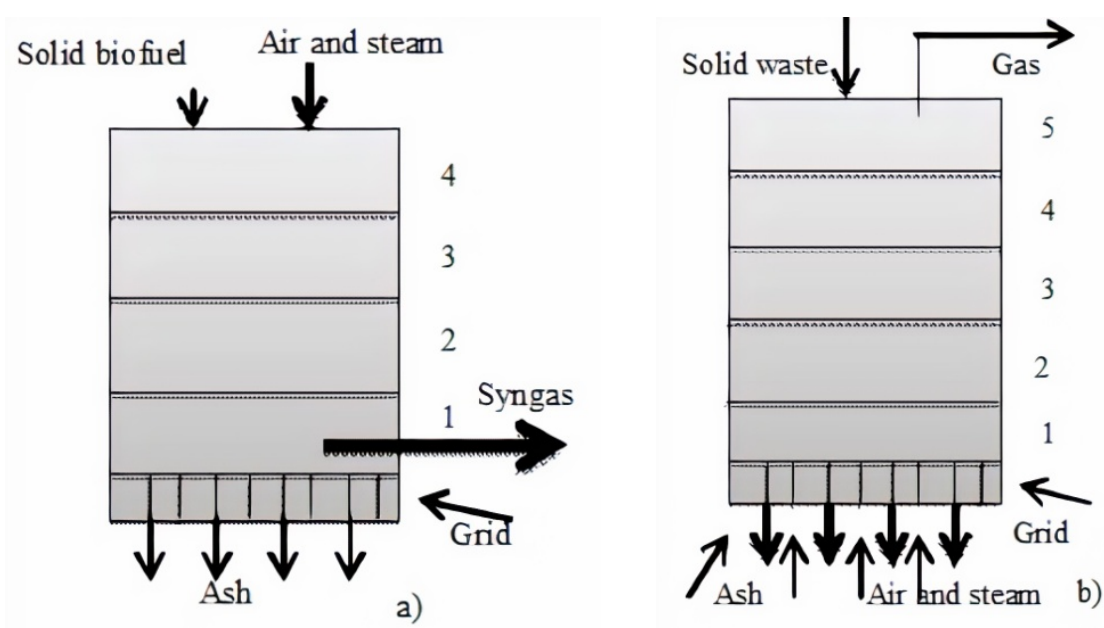

Fig. 1. The thermochemical processes in the body of a gasifier a) updraft; b) downdraft

For updraft flow, zone 1 represents the ash cooling, zone 2 is the combustion zone (temperature range between 1000 and $1300^{\circ} \mathrm{C}$ ), zone 3 is the reduction zone, zone 4 is the preheating process (pyrolysis), with a temperature range within $600-800{ }^{\circ} \mathrm{C}$, and zone 5 is characteristic to the drying process.

For the downdraft flow, the characteristic areas follow the same order (1-heating, 2pyrolysis, 3-combustion, 4-reduction). The technology is suitable for low humidity biomass because heating and dehydration is not aided by burning of the fuel. Instead, the temperature in the reduction zone is maximum, close to that of combustion in the fuel layer. There have been developed also systems of air supply with transverse flow, derived from the application of the flow for both presented technologies. The system implemented in this research partially feeds with air the pyrolysis area, and continues to be distributed mainly in the combustion zone. The air in the end zone of the pyrolysis process ensures the ignition of the released volatiles and the preparation of the solid phase combustion process, as depicted in Figure 2 and Figure 3 [14], [15].

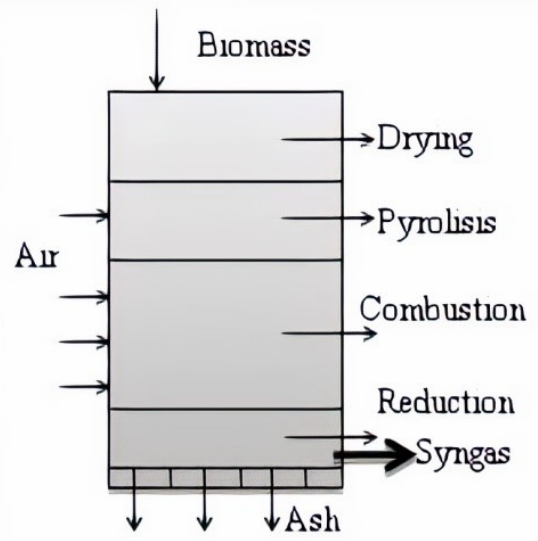

Fig. 2. Installation with homogeneous distribution of air

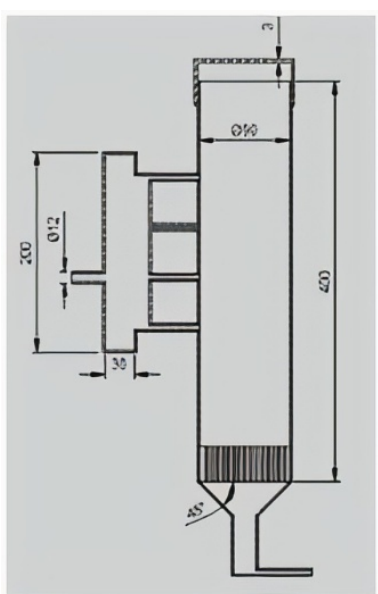

Fig. 3. The experimental installation 


\section{The experimental installation}

The experimental installation is designed to produce gasifier gas using an inlet rate up to 1 $\mathrm{kg}$ of biomass per hour. The installation shown in Figure 3 uses a discontinuous supply system. The gaseous fuel passes through the ash, being discharged beneath it.

For the initial phase of the research, wood (beech species) with low humidity (9-14\%), calorific power was considered within the range:

$H_{i}^{i}=14200-14700\left[\frac{\mathrm{kJ}}{\mathrm{kg}}\right]$. The theoretical volume of air is $V_{a}^{0}=3.8-3.9\left[\frac{\mathrm{m}_{N}^{3}}{\mathrm{~kg}}\right]$,

while the total volume of combustion gases is evaluated at $V_{g}^{0}=4.6-4.9\left[\frac{m_{N}^{3}}{\mathrm{~kg}}\right]$.

Moreover, the theoretical volume of $\mathrm{CO}_{2}$ is $V_{\mathrm{CO}_{2}}^{0}=0.8-0.85\left[\frac{\mathrm{m}_{\mathrm{N}}^{3}}{\mathrm{~kg}}\right]$

and the theoretical volume of steam is $V_{\mathrm{H}_{2} \mathrm{O}}^{0}=0.8-0.9\left[\frac{\mathrm{m}_{\mathrm{N}}^{3}}{\mathrm{~kg}}\right]$.

On the second phase of the research, the influence of humidity on the gasification process is assessed by employing wood with an average humidity of $37 \%$. The experimental stand is presented in Figure 4, including an air supply compressor and a two rotameter system to allow the measurement and control of the inlet.

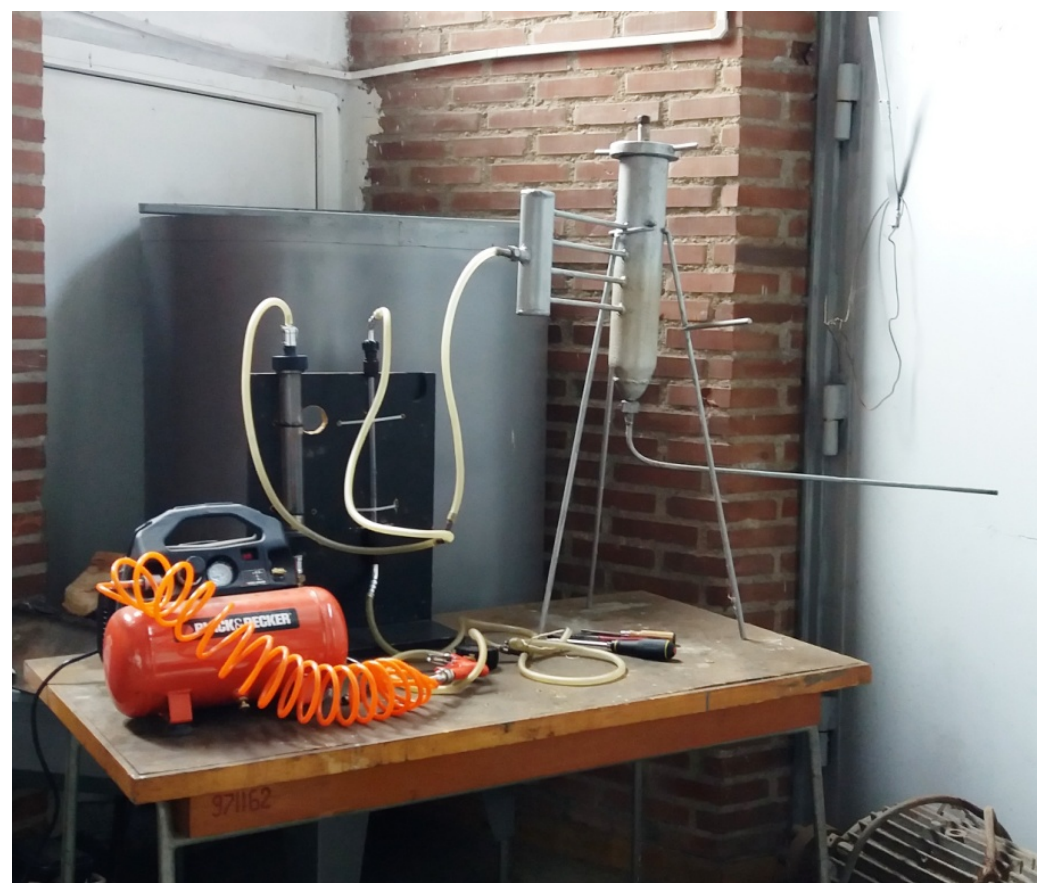

Fig. 4. Experimental stand.

The temperature of the gasifier body was monitored continuously using a contact thermometer or a thermal imaging chamber. The syngas is evacuated in the environment, having the possibility to easily measure its flow, temperature and its composition. Figure 5 shows the combustion of syngas when discharged into the environment and the appearance of the flame is highlighted on the right side. The temperature of the outside of the gasifier body, measured by a thermal vision camera is shown in Figure 6. 


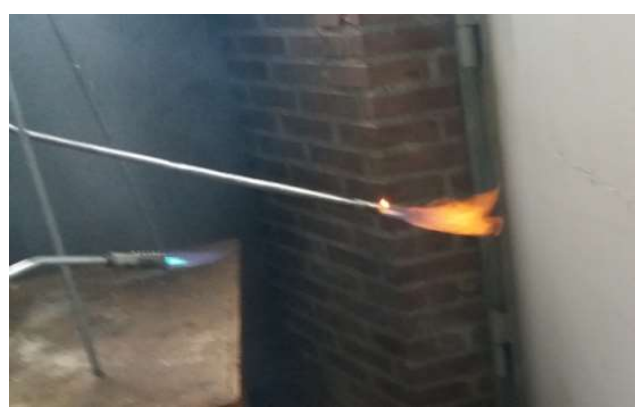

Fig. 5. Evacuation of the syngas for the experiment with the dry wood

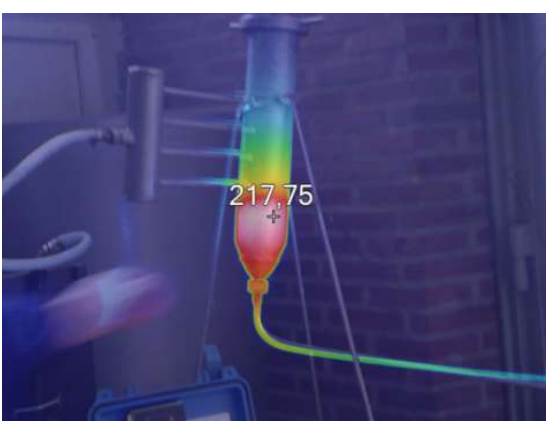

Fig. 6. Temperature measurement with the thermal imaging chamber

\section{Results}

The first round of results refer to dry wood, with the following characteristics:

- humidity $W_{t}^{i}<12.2 \%$;

- lower heating value $H_{i}^{i}=16000-16500\left[\frac{\mathrm{kJ}}{\mathrm{kg}}\right]$;

- particles size $0-15 \mathrm{~mm}$;

For this fuel, the air flow rate was $V_{a}^{0}=1.2-1.5\left[\frac{m_{N}^{3}}{h}\right]$. Figure 7 pictures the analyzer.

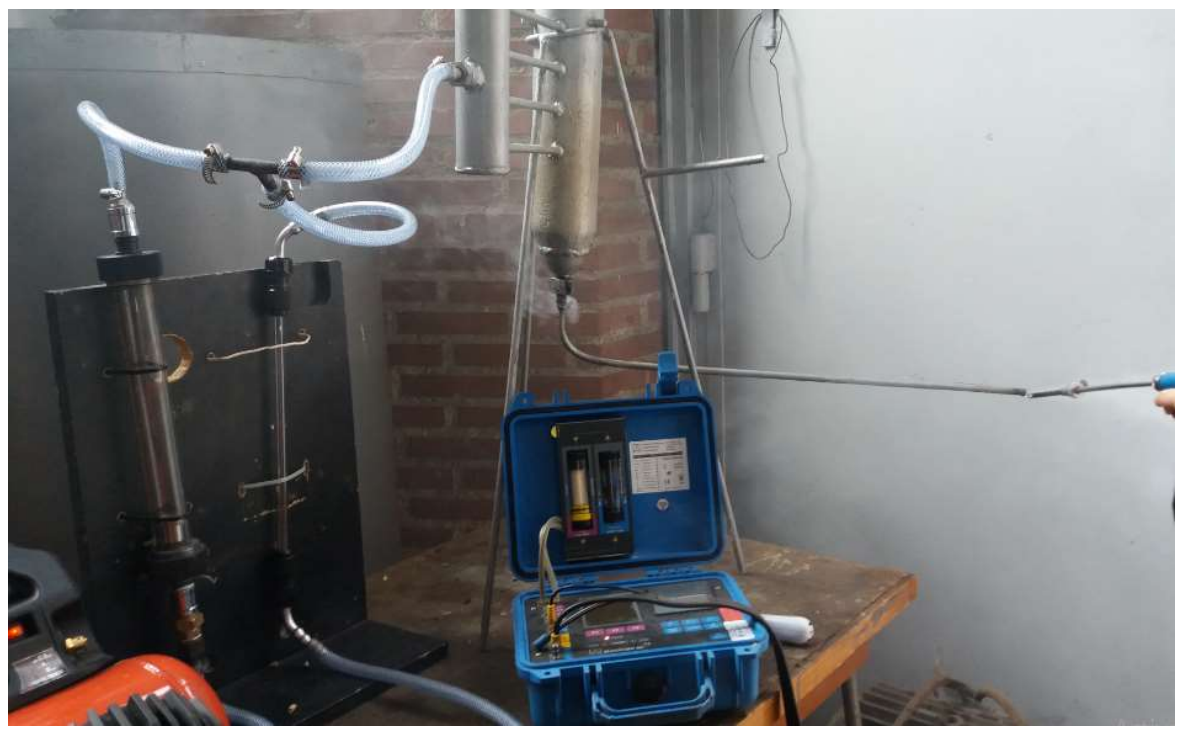

Fig. 7. The measure of syngas composition

According to the measurements results, the average composition of the syngas, results as: $\mathrm{CO}=4.8 \% ; \mathrm{CO}_{2}=8.4 \% ; \mathrm{N}_{2}=55 \% ; \mathrm{CH}_{4}+\mathrm{H}_{2}=31.8 \%$.

The analysis of the syngas was carried out in the combustion section of the installation in order not to take into account the flow of air driven through the environment by the gas jet. For a ratio $\frac{\mathrm{H}_{2}}{\mathrm{CH}_{4}} \cong 4$ it results: $\mathrm{CH}_{4}=6.36 \%$ and $\mathrm{H}_{2}=25.44 \%$. The lower heating value is: 


$$
H_{i}^{i}=0.084 * 12644+0.0636 * 35700+0.254 * 10760=5614.61\left[\frac{\mathrm{kJ}}{\mathrm{m}_{N}^{3}}\right]
$$

The second round of results is obtained for biomass with $37 \%$ humidity, it was observed the increase of the participation of carbon oxide and the decrease of the one of hydrogen in the gas produced by gasification. The average composition was: $\mathrm{CO}=5.7 \% ; \mathrm{CO}_{2}=9.5 \%$; $\mathrm{N}_{2}=54 \% ; \mathrm{CH}_{4}=7.7 \% ; \mathrm{H}_{2}=23.1 \%$. For what concerns the lower heating value, it is evaluated at:

$$
H_{i}^{i}=0.057 * 12644+0.077 * 35700+0.231 * 10760=5955.1\left[\frac{k J}{m_{N}^{3}}\right]
$$

The reason why the net calorific value is higher in second case than in first one is because the content of methane and carbon oxide is higher in this case due to it's high moisture content.

\section{Conclusions}

In this work, on the basis of theoretical studies, the potential of gasification of biomass was demonstrated, and through experimental work, was demonstrated the possibility of gasification of wood in the created laboratory facility. More in detail, the process is researched by using only the reduction processes from the final stage with a gasification agent represented only by air.

The pilot plant under study is equipped with discontinuous fuel supply and has a thermal power of $3.3 \mathrm{~kW}$ and a combustion under a slight air overpressure.

A cross-sectional distribution over the entire area of chemical combustion reactions of air was used.

During the experimental investigations, the humidity of the wood varies within the range $12.2 \%$ to $37 \%$. The gas flow rate was $2.06 \mathrm{~m}_{N}^{3} / \mathrm{h}$ for a wood flow of $0.5 \mathrm{~kg} / \mathrm{h}$.

This work was supported by a grant from the Romanian Ministry of Research and Innovation, CCCDI-UEFISCDI, project number PN-III-P1-1.2-PCCDI-2017- 0404/31PCCD/2018, within PNCDI.

\section{Nomenclature}

$\mathrm{n}_{\mathrm{H}_{2}}$ hydrogen moles [kmol]

$\mathrm{n}_{\mathrm{CO}}$ carbon monoxide moles [kmol]

$\mathrm{n}_{\mathrm{CO}_{2}}$ carbon dioxide moles [kmol]

$\mathrm{n}_{\mathrm{H}_{2} \mathrm{O}}$ water moles [kmol]

$\mathrm{n}_{\mathrm{CH}_{4}}$ methane moles [kmol]

$\mathrm{n}_{\mathrm{N}_{2}}$ nitrogen moles [kmol]

$\mathrm{n}_{\mathrm{O}_{2}}$ oxygen moles [kmol]

$\mathrm{n}_{\mathrm{C}}$ carbon moles [kmol]

$\mathrm{n}_{\mathrm{NO}}$ nitrogen oxide moles [kmol]

$\mathrm{n}_{\mathrm{NO}_{2}}$ nitrogen dioxide moles [kmol]

$\mathrm{n}_{\mathrm{SO}_{2}}$ sulfur dioxide moles [kmol]

$K$ equilibrium constant

$n \mathrm{kmol}$ of oxygen per kmol of biomass

$m$ kmol of steam per kmol of biomass

$T$ temperature $[\mathrm{K}]$ and $\left[{ }^{\circ} \mathrm{C}\right]$
$P$ pressure [bar]

$\Delta G$ change in Gibbs function

$\eta$ efficiency [\%]

w moisture content [\%]

$\mathrm{H}_{\mathrm{i} \text { gas }}^{\mathrm{i}}$ lower calorific power of the gas $\left[\frac{\mathrm{kJ}}{\mathrm{m}_{\mathrm{N}}^{3}}\right]$

$\mathrm{H}_{\mathrm{i}}^{\mathrm{i}}$ fuel lower calorific power of the fuel $\left[\frac{\mathrm{kJ}}{\mathrm{kg}}\right]$

$\mathrm{G}_{\mathrm{V}}$ gas yield during the whole gasification $\left[\frac{\mathrm{m}_{\mathrm{N}}^{3}}{\mathrm{~kg}}\right]$

$V_{a}^{0}$ theoretical volume of air $\left[\frac{\mathrm{m}_{\mathrm{N}}^{3}}{\mathrm{~kg}}\right]$

$\mathrm{V}_{\mathrm{g}}^{0}$ volume of combustion gases $\left[\frac{\mathrm{m}_{\mathrm{N}}^{3}}{\mathrm{~kg}}\right]$

$\mathrm{V}_{\mathrm{CO}_{2}}^{0}$ theoretical volume of $\mathrm{CO}_{2}\left[\frac{\mathrm{m}_{\mathrm{N}}^{3}}{\mathrm{~kg}}\right]$

$\mathrm{V}_{\mathrm{H}_{2} \mathrm{O}}^{0}$ theoretical volume of steam $\left[\frac{\mathrm{m}_{\mathrm{N}}^{3}}{\mathrm{~kg}}\right]$ 


\section{References}

1. L. Mihaescu et al., "Achievements in energy valorization of cereal straw in boiler manufactured in Romania," in 5th International Conference on Trends in Agricultural Engineering, pp. 417-421, (2013)

2. E. Shayan, V. Zare, and I. Mirzaee, "Hydrogen production from biomass gasification; a theoretical comparison of using different gasification agents," Energy Convers. Manag., vol. 159, no. January, pp. 30-41, (2018)

3. G. Lazaroiu et al., "Experimental Investigations of Innovative Biomass Energy Harnessing Solutions," Energies, vol. 11, no. 12, p. 3469, (2018)

4. C. Colpan, F. Hamdullahpur, I. Dincer, and Y. Yoo, "Effect of gasification agent on the performance of solid oxide fuel cell and biomass gasification systems," Int. J. Hydrogen Energy, vol. 35, pp. 5001-9, (2010)

5. Z. Zainal, R. Ali, C. Lean, and K. Seetharamu, "Prediction of performance of a downdraft gasifier using equilibrium modeling for different biomass materials," Energy Convers. Manag., vol. 42, pp. 1499-515, (2001)

6. S. Sansaniwal, K. Pal, M. Rosen, and S. Tyagi, "Recent advances in the development of biomass gasification technology: a comprehensive review," Renew. Sustain. Energy Rev., vol. 72, pp. 368-84, (2017)

7. I. Carabogdan, A. Badea, L. Ionescu, A. Leca, I. Nistor, and I. Cserveny, Industrial termical installtion. Bucharest: Editura Tehnica Bucuresti, (1978)

8. E. Gholamian, V. Zare, and S. Mousavi, "Integration of biomass gasification with a solid oxide fuel cell in a combined cooling, heating and power system: a thermodynamic and environmental analysis," Int. J. Hydrogen Energy, vol. 41, pp. 20396-406, (2016)

9. E. Gholamian, "Proposal, exergy analysis and optimization of a new biomass-based cogeneration system," Appl. Therm. Eng., vol. 93, pp. 223-35, (2016)

10. C. Altafini, "Prediction of the working parameters of a wood waste gasifier through an equilibrium model," Energy Convers. Manag., vol. 44, pp. 2763-3277, (2003)

11. G. Schuster, G. Loffler, K. Weigl, and H. Hofbauer, "Biomass steam gasification- an extensive parametric modeling study," Bioresour. Technol., vol. 77, pp. 71-9, (2001)

12. E. Balu, U. Lee, and J. Chung, "High temperature steam gasification of woody biomass - a combined experimental and mathematical modeling approach," Int. J. Hydrogen Energy, vol. 40, pp. 14104-15, (2015)

13. G. Lazaroiu et al., "Biomass combustion with hydrogen injection for energy applications," Energy, vol. 127, pp. 351-357, (2017)

14. I. Pisa, G. Lazaroiu, L. Mihaescu, T. Prisecaru, and G. Negreanu, "Mathematical model and experimental tests of hydrogen diffusion in the porous system of biomass," Int. J. Green Energy, (2016)

15. A. D. Bondrea, G. Lazaroiu, L. Mihaescu, and V. Berbece, "The particularities flame to burning bio-fuels," in International Multidisciplinary Scientific GeoConference Surveying Geology and Mining Ecology Management, SGEM, (2018) 